\title{
LIQUID DIFFUSION DURING DRYING OF SORGHUM GRAINS UNDER DIFFERENT CONDITIONS
}

\section{Lígia C. de M. Silva ${ }^{*}$, Osvaldo Resende ${ }^{1}$, Daniel E. C. de Oliveira ${ }^{2}$, Weder N. Ferreira Junior ${ }^{1}$, Gabrielly B. Rodrigues ${ }^{1}$}

${ }^{1 *}$ Corresponding author. Instituto Federal de Educação, Ciência e Tecnologia Goiano - Campus Rio Verde/ Rio Verde - GO, Brasil. E-mail: ligialirios@hotmail.com | ORCID ID: https://orcid.org/0000-0001-9058-975X

\section{KEYWORDS}

diffusion coefficient, activation energy, Sorghum bicolor $\mathrm{L}$.

\begin{abstract}
Drying is the most widely used process to ensure the quality and stability of plant products. Therefore, this study aimed to determine the effective water diffusivity and activation energy in grain sorghum during drying at different temperatures and initial moisture contents. Sorghum grains (cultivar DeKalb 640) were harvested with an initial moisture content of $0.49 \mathrm{~kg}$ water kg-1 dry matter. The effective diffusion coefficient was determined from different initial moisture contents of approximately $0.49,0.40,0.31$, and $0.23 \mathrm{~kg}$ water $\mathrm{kg}^{-1}$ dry matter. Grains with different moisture contents were dried under four temperature conditions of $40,60,80$, and $100{ }^{\circ} \mathrm{C}$ on perforated trays. The spherical geometry model was used for liquid diffusion. The experiment was conducted in a completely randomized design in a $4 \times 4$ factorial scheme (four moisture contents $\times$ four temperatures), with three replications. Data were subjected to analysis of variance and regression using the statistical software SISVAR ${ }^{\circledR}$. Sorghum grain diffusivity increases at the same drying temperature as an increase of the initial moisture content of grains. The activation energy was higher for grains with higher initial moisture content, with values of $27.32,26.75,22.55$, and $20.94 \mathrm{~kJ} \mathrm{~mol}^{-1}$, respectively.
\end{abstract}

\section{INTRODUCTION}

Sorghum (Sorghum bicolor L.) belongs to the grass family and is the fifth most-produced cereal in the world. Sorghum cultivated area in Brazil is estimated at 626.5 thousand hectares, with a grain production of 1.845 million tons and average yield of 2.97 tons $\mathrm{ha}^{-1}$. The state of Goiás leads the national production, with 851.5 thousand tons. In second place, with 499.7 thousand tons, is Minas Gerais, followed by Mato Grosso, with 291.5 thousand tons (Conab, 2017).

Drying is the most widely used process in the postharvest phase to ensure quality and stability of plant products, as a decreasing moisture content reduces the biological activity in the grain mass, as well as chemical and physical changes that occur during storage (Araújo et al., 2014), reduces weight and volume occupied during processing and marketing, protects against degradation reactions, and makes them available at any time of the year. Also, it contributes to nutrient concentration because water is removed from the product (Fernandes et al., 2014).
The modeling of drying curves determines physical and thermodynamic indices related to heat and mass transfers and equipment sizing, allowing comparing the drying between different species or materials and evaluating the peculiarities of products, being one of the most important indices the diffusion coefficient (Botelho et al., 2015).

The liquid diffusion model has been studied and stands out among the theoretical models applied to the drying process of plant products, whose parameters are not strictly representative of the various mechanisms that prevail in the water transport in agricultural products. Researchers such as Araújo et al. (2017) have relied on the theory of liquid diffusion to establish liquid diffusion as a function of the concentration gradient.

Due to diffusivity variation as the drying conditions change, this study aimed to determine the effective water diffusivity and activation energy in grain sorghum grains during drying at different temperatures and initial moisture contents.

\footnotetext{
${ }^{1}$ Instituto Federal de Educação, Ciência e Tecnologia Goiano - Campus Rio Verde/ Rio Verde - GO, Brasil.

${ }^{2}$ Instituto Federal de Educação, Ciência e Tecnologia Goiano - Campus Iporá/ Iporá - GO, Brasil.

Received in: 6-26-2018
}

Accepted in: 10-7-2019 


\section{MATERIAL AND METHODS}

The experiment was conducted at the Laboratory of Postharvest of Plant Products of the Federal Institute of Education, Science and Technology Goiano (IF Goiano), Campus of Rio Verde. Sorghum grains (cultivar DeKalb 640) were harvested manually in Jataí (GO), with an initial moisture content of $0.49 \mathrm{~kg}$ water $\mathrm{kg}^{-1}$ dry matter. Grain processing was performed by means of sieves for precleaning and a homogenizer.

Three moisture contents of grains were obtained in a greenhouse with a drying temperature of $40{ }^{\circ} \mathrm{C}$ from their initial moisture content of $0.49 \mathrm{~kg}$ water $\mathrm{kg}^{-1}$ dry matter. The reduction in the moisture content was analyzed by gravimetry and stipulated moisture contents of 0.40 , 0.31 , and $0.23 \mathrm{~kg}$ water $\mathrm{kg}^{-1}$ dry matter were obtained. Thus, the effective diffusion coefficient was determined from different initial moisture contents of approximately $0.49,0.40,0.31$, and $0.23 \mathrm{~kg}$ water $\mathrm{kg}^{-1}$ dry matter. Grains with different moisture contents were submitted to drying in a forced air ventilation oven at four temperature conditions $\left(40,60,80\right.$, and $\left.100{ }^{\circ} \mathrm{C}\right)$ in perforated trays with $250 \mathrm{~g}$ of grains. The average ambient air temperature was $25.3 \pm 1.1{ }^{\circ} \mathrm{C}$ and the relative humidity of $39.8 \pm 2.3 \%$ throughout the drying period.

The drying process (Table 1) was interrupted when sorghum grains reached final moisture contents of $0.14 \pm 0.007 \mathrm{~kg}$ water $\mathrm{kg}^{-1}$ dry matter for temperatures of $40,60,80$, and $100{ }^{\circ} \mathrm{C}$, respectively, determined in an oven at $105 \pm 1{ }^{\circ} \mathrm{C}$ for $24 \mathrm{~h}$, with three replications.

The following expression was used to determine sorghum moisture content ratios during drying:

$$
\mathrm{RX}=\frac{\mathrm{X}-\mathrm{X}_{\mathrm{e}}}{\mathrm{X}_{\mathrm{i}}-\mathrm{X}_{\mathrm{e}}}
$$

Where,

$\mathrm{RX}$ is the moisture content ratio;

$\mathrm{X}$ is the moisture content of the product ( $\mathrm{kg}$ water $\mathrm{kg}^{-1}$ dry weight);

$\mathrm{X}_{\mathrm{i}}$ is the initial moisture content of the product $(\mathrm{kg}$ water $\mathrm{kg}^{-1}$ dry matter), and

$\mathrm{X}_{\mathrm{e}}$ is the equilibrium moisture content of the product ( $\mathrm{kg}$ water $\mathrm{kg}^{-1}$ dry matter).

Moisture content reduction during the drying process was analyzed by the gravimetric method (mass loss) using an analytical balance with a resolution of 0.01 $\mathrm{g}$, knowing the initial moisture content of the product until reaching the desired moisture content.

The liquid diffusion was described by an eight-term approximation spherical geometry model, according to the following expression:

$$
\mathrm{RX}=\frac{6}{\pi^{2}} \sum_{\mathrm{n}=1}^{\infty} \frac{1}{\mathrm{n}^{2}} \exp \left[-\frac{\mathrm{n}^{2} \cdot \pi^{2} \cdot \mathrm{D} \cdot \mathrm{t}}{\mathrm{r}}\right]
$$

Where,

$\mathrm{n}$ is the number of terms,

$\mathrm{D}$ is the liquid diffusion coefficient $\left(\mathrm{m}^{2} \mathrm{~s}^{-1}\right)$, and

$r$ is the equivalent radius $(\mathrm{m})$.
The equivalent radii of sorghum grains were determined by the following expression:

$$
r=\sqrt[3]{\frac{3 \cdot V_{g}}{4 \cdot \pi}}
$$

Where,

$$
\mathrm{V}_{\mathrm{g}} \text { is the grain volume }\left(\mathrm{m}^{-3}\right) \text {. }
$$

The volume of each sorghum grain $\left(\mathrm{V}_{\mathrm{g}}\right)$ was obtained by measuring its three orthogonal axes (length, width, and thickness) in fifteen units at the end of drying, using a digital caliper with a $0.01-\mathrm{mm}$ resolution, according to the following expression:

$$
\mathrm{V} g=\frac{\pi \cdot \mathrm{a} \cdot \mathrm{b} \cdot \mathrm{c}}{6}
$$

Where,

$\mathrm{a}$ is the length $(\mathrm{m})$;

$\mathrm{b}$ is the width (m), and

$\mathrm{c}$ is the thickness (m).

The relationship between the effective diffusion coefficient and the increase in the drying air temperature was described by the Arrhenius equation:

$$
\mathrm{D}=\mathrm{D}_{\mathrm{o}} \cdot \exp \left(\frac{-\mathrm{E}_{\mathrm{a}}}{\mathrm{R} \cdot \mathrm{T}_{\mathrm{abs}}}\right)
$$

Where,

$$
\begin{aligned}
& D_{o} \text { is the pre-exponential factor, } \\
& E_{a} \text { is the activation energy }\left(\mathrm{kJ} \mathrm{mol}^{-1}\right) \text {, } \\
& \mathrm{R} \text { is the universal gas constant }\left(8.134 \mathrm{~kJ} \mathrm{kmol}^{-1}\right. \\
& \left.\mathrm{K}^{-1}\right) \text {, and } \\
& T_{\mathrm{abs}} \text { is the absolute temperature }(\mathrm{K}) \text {. }
\end{aligned}
$$

The coefficients of the Arrhenius expression can be easily obtained by linearizing [eq. (6)] with logarithm application, as follows:

$$
\operatorname{LnD}=\operatorname{LnD}_{\mathrm{O}}-\frac{\mathrm{E}_{\mathrm{a}}}{\mathrm{R}} \cdot \frac{1}{\mathrm{~T}_{\mathrm{ab}}}
$$

The experiment was conducted in a completely randomized design in a $4 \times 4$ factorial scheme (four moisture contents $\times$ four drying temperatures), with three replications. Diffusion coefficient data were subjected to analysis of variance and regression using the statistical software SISVAR ${ }^{\circledR}$. The models were selected based on the significance of equation by the F-test, significance of regression coefficients using the $\mathrm{t}$-test at $5 \%$ significance level, and the coefficient of determination.

\section{RESULTS AND DISCUSSION}

Figure 1 shows the drying curves of grain sorghum for temperatures of $40,60,80$, and $100{ }^{\circ} \mathrm{C}$, with different initial moisture contents of $0.49,0.40,0.31$, and $0.23 \mathrm{~kg}$ water $\mathrm{kg}^{-1}$ dry weight. 
A)

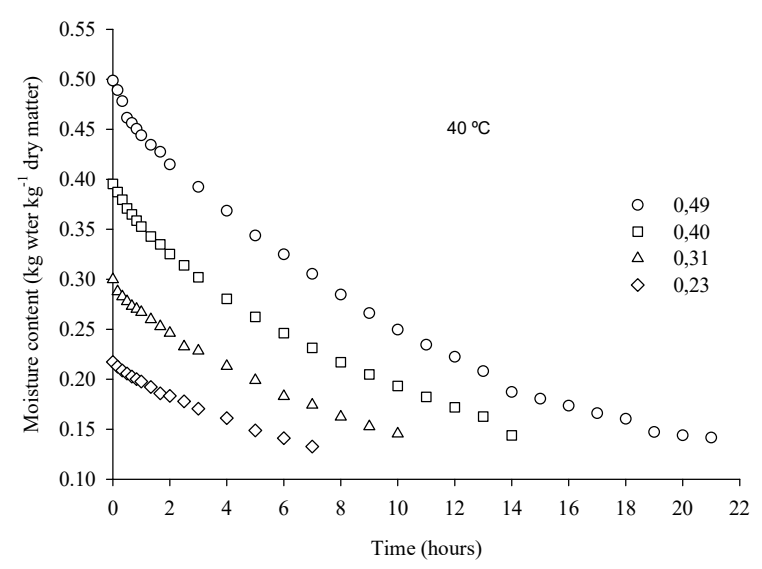

C)

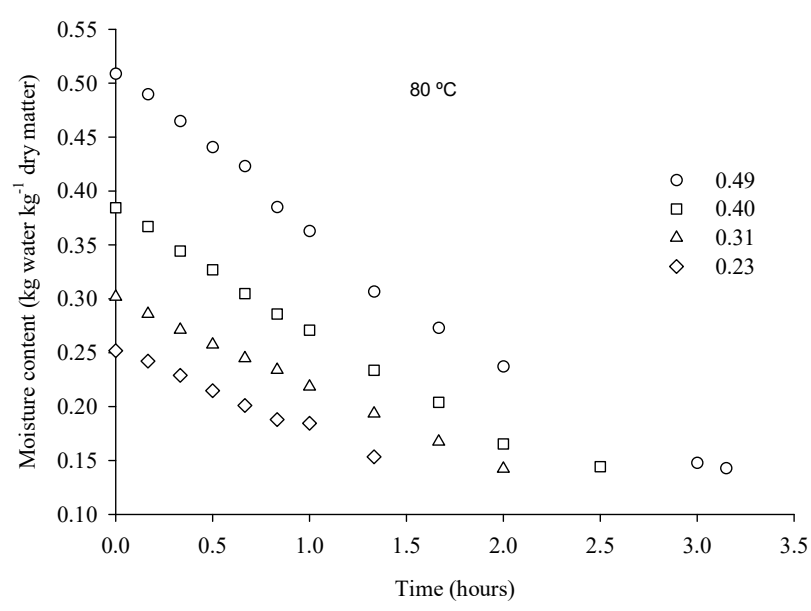

B)

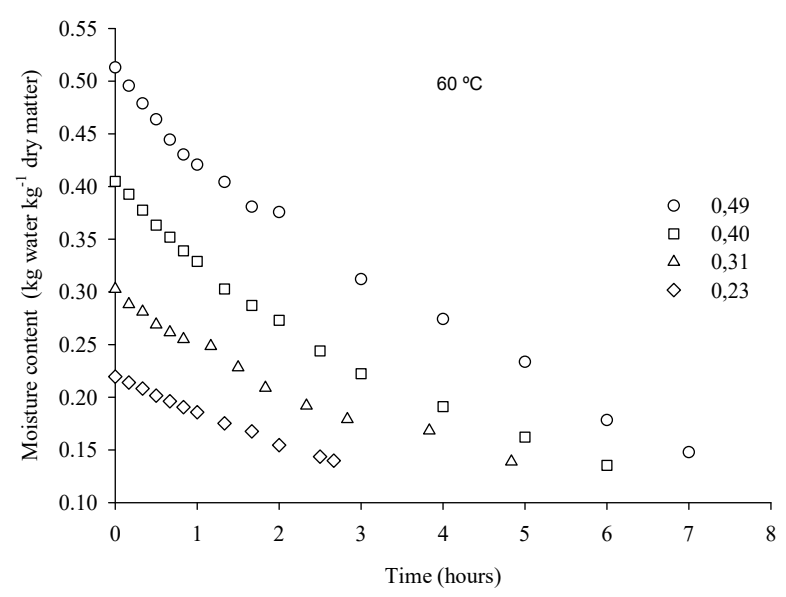

D)

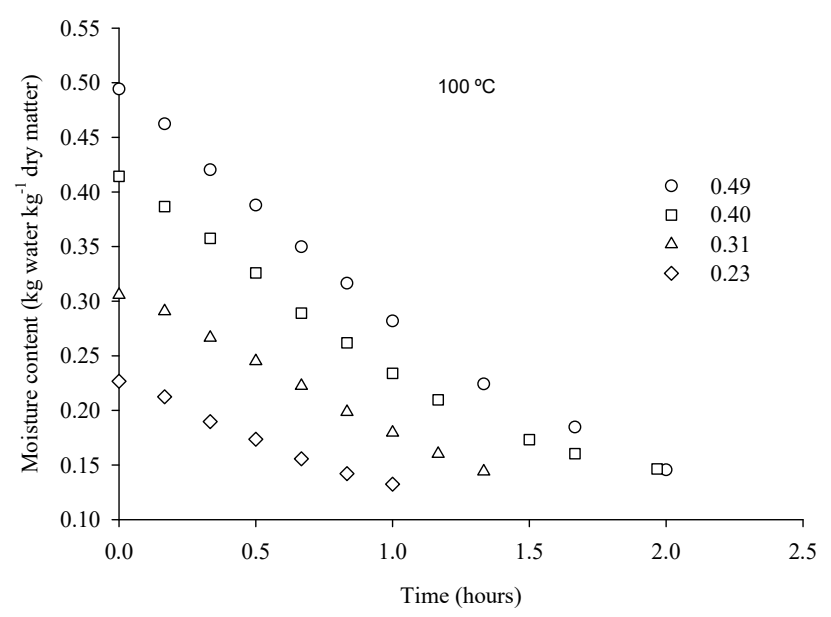

FIGURE 1. Moisture content of grain sorghum throughout drying at different temperatures: (A) $40{ }^{\circ} \mathrm{C}$, (B) $60{ }^{\circ} \mathrm{C}$, (C) $80{ }^{\circ} \mathrm{C}$, and (D) $100^{\circ} \mathrm{C}$.

Temperature increases as drying time decreases, and higher initial moisture contents need longer drying time when compared to the smaller contents to reach a moisture content of $0.14 \mathrm{~kg}$ water $\mathrm{kg}^{-1}$ dry matter. It is due to the increased availability of energy for water vaporization to occur and the increase in the mass transfer coefficient as drying air temperature increases. Thus, it shows that drying kinetics of sorghum grains has similar behavior to most agricultural products observed by several researchers (Baptestini et al., 2015; Rodovalho et al., 2015; Oliveira et al., 2014).

Table 1 shows the time required for drying at each temperature and moisture content until reaching the final moisture contents of $0.14 \pm 0.007 \mathrm{~kg}$ water $\mathrm{kg}^{-1}$ dry matter. The lowest moisture contents with the shortest drying time stand out as the temperature increases.

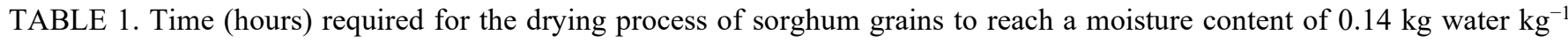
dry weight under different conditions.

\begin{tabular}{ccccc}
\hline \multirow{2}{*}{ Temperature $\left({ }^{\circ} \mathrm{C}\right)$} & \multicolumn{4}{c}{ Initial moisture content $\left({\left.\mathrm{kg} \mathrm{water} \mathrm{kg}^{-1} \text { dry matter }\right)}\right.$} \\
\cline { 2 - 4 } & 0.23 & 0.31 & 0.40 & 0.49 \\
\hline 40 & 7.0 & 10.0 & 14.0 & 21.0 \\
60 & 2.6 & 4.8 & 6.0 & 7.0 \\
80 & 1.33 & 2.0 & 2.5 & 3.15 \\
100 & 1.0 & 1.33 & 1.97 & 2.0 \\
\hline
\end{tabular}


Sorghum grain diffusivity increased at the same drying temperature as the initial moisture content of grain increased (Figure 2).

Increases of $0.0173,0.0201,0.0280$, and $0.0298 \mathrm{~m}^{2}$ $\mathrm{s}^{-1}$ were observed in the effective diffusion coefficient for moisture contents of $0.23,0.31,0.40$, and $0.49 \mathrm{~kg}$ water $\mathrm{kg}^{-1}$ dry matter, respectively, for each $1{ }^{\circ} \mathrm{C}$ increase in temperature (Figure 2). An increasing linear behavior was observed between the different moisture contents for drying temperatures, with values varying from 0.23 to 0.49

A)

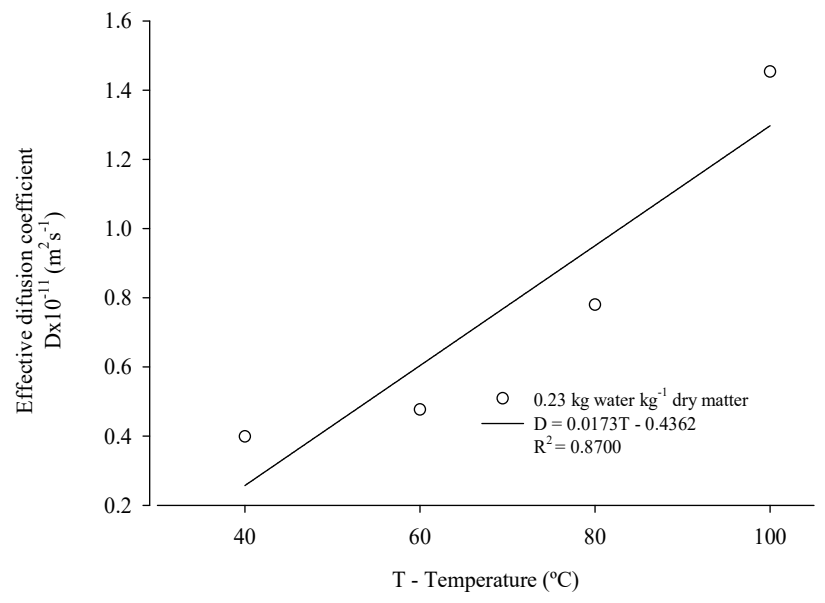

C)

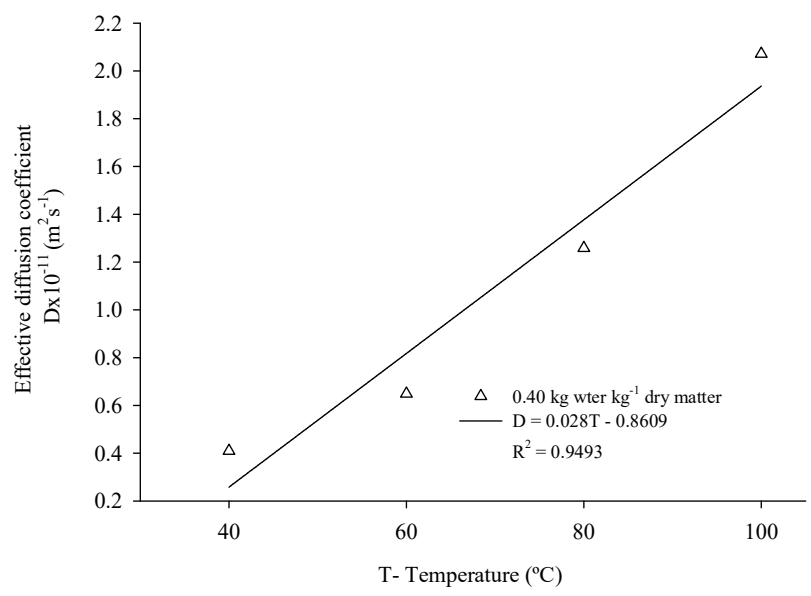

$\mathrm{kg}$ water $\mathrm{kg}^{-1}$ dry matter, from $0.39 \times 10^{-11}$ to $0.45 \times 10^{-11}$ $\mathrm{m}^{2} \mathrm{~s}^{-1}$, respectively, at a temperature of $40^{\circ} \mathrm{C}$. The values of the diffusion coefficient ranged from $0.47 \times 10^{-11}$ to $0.69 \times 10^{-11} \mathrm{~m}^{2} \mathrm{~s}^{-1}, 0.78 \times 10^{-11}$ to $1.43 \times 10^{-11} \mathrm{~m}^{2} \mathrm{~s}^{-1}$, and $1.44 \times 10^{-11}$ to $2.43 \times 10^{-11} \mathrm{~m}^{2} \mathrm{~s}^{-1}$ for temperatures of 60 , 80 , and $100{ }^{\circ} \mathrm{C}$, respectively. These results are consistent with those reported in the literature for drying agricultural products, which range from $10^{-9}$ to $10^{-11} \mathrm{~m}^{2} \mathrm{~s}^{-1}$, according to Madamba et al. (1996).

B)

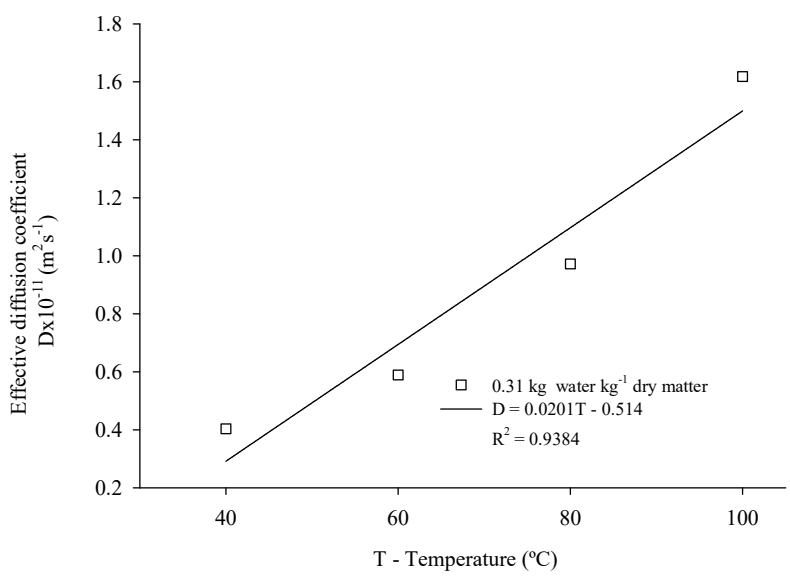

D)

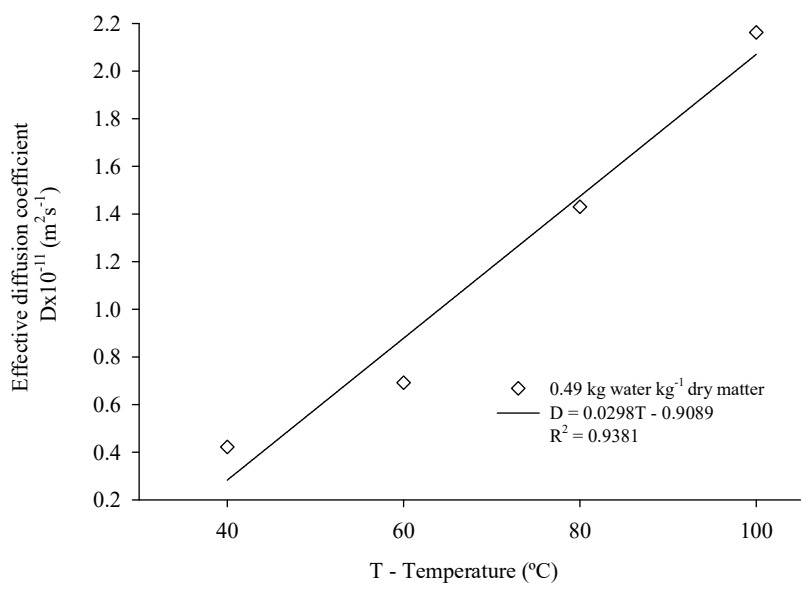

FIGURE 2. Values of effective diffusion coefficient $\left(\mathrm{m}^{2} \mathrm{~s}^{-1}\right)$ obtained for drying of sorghum grains at different temperatures and initial moisture contents of 0.23 (A) 0.31 (B) 0.40 (C), and $0.49 \mathrm{~kg}$ water kg $^{-1}$ dry matter (D).

There was an effect of temperature and initial moisture content on the effective diffusion coefficient. An increase in the drying air temperature leads to a decrease in viscosity, which represents the fluid resistance to water flow, resulting in alterations in water diffusion in the capillaries of sorghum grains, favoring the movement of this fluid in the product (Goneli et al., 2009). Consequently, a reduction in moisture content causes a decrease in fluid resistance, positively affecting drying.
The drying temperature of $40{ }^{\circ} \mathrm{C}$ (Figure 3 ) led to a lower variation in the diffusion coefficient, with values of $0.39 \times 10^{-11}, 0.40 \times 10^{-11}, 0.42 \times 10^{-11}$, and $0.45 \times 10^{-11}$ for moisture contents of $0.23,0.31,0.40$, and $0.49 \mathrm{~kg}$ water $\mathrm{kg}^{-1}$ dry matter, respectively. The tendency to reduce diffusivity with a decreasing grain initial moisture content was linear. The difference in the diffusion coefficients between initial moisture contents presented higher variations as the drying temperature increased, following a linear behavior of higher diffusivity for grains with higher moisture contents. 
A)

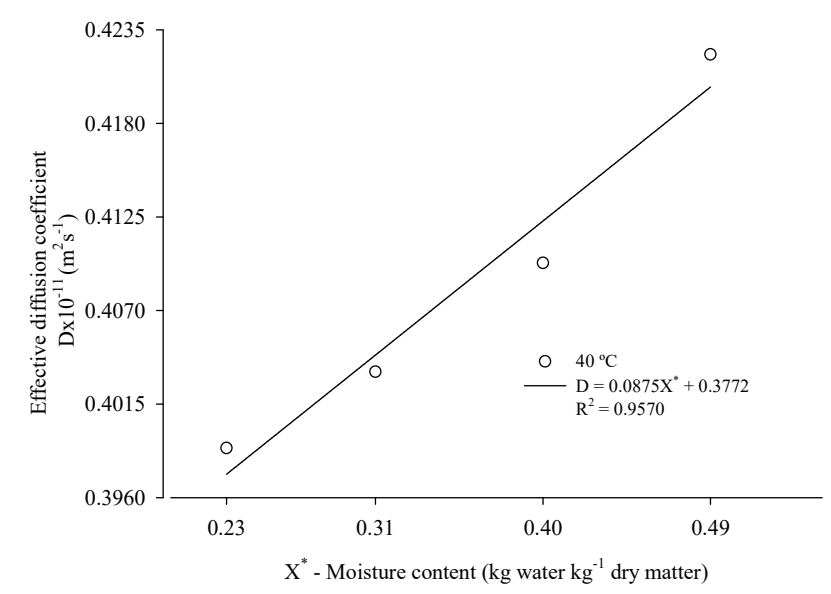

C)

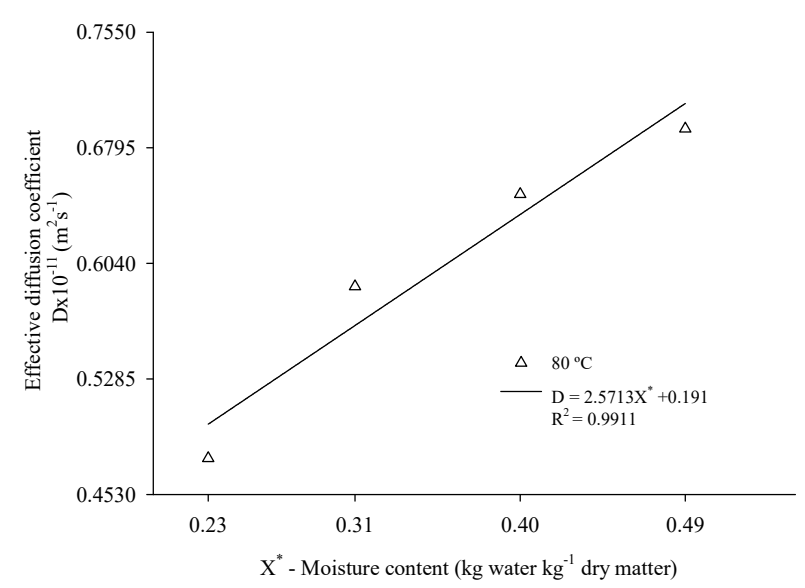

B)

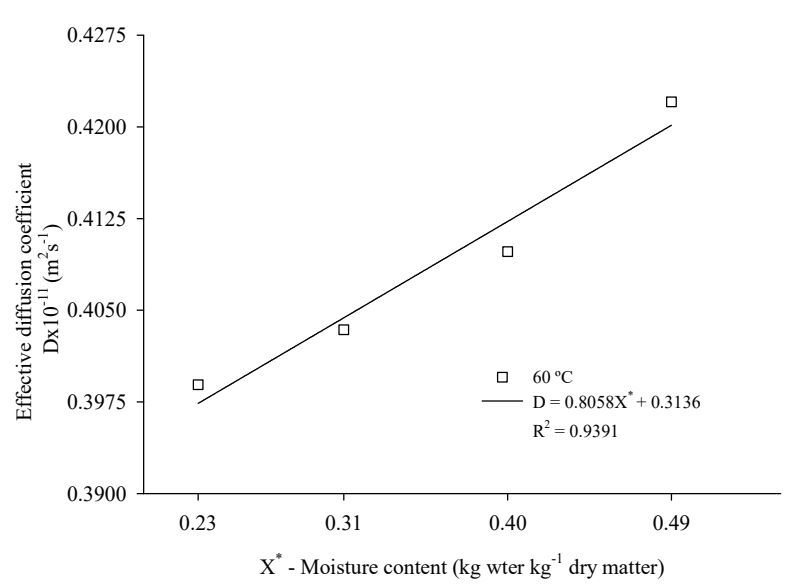

D)

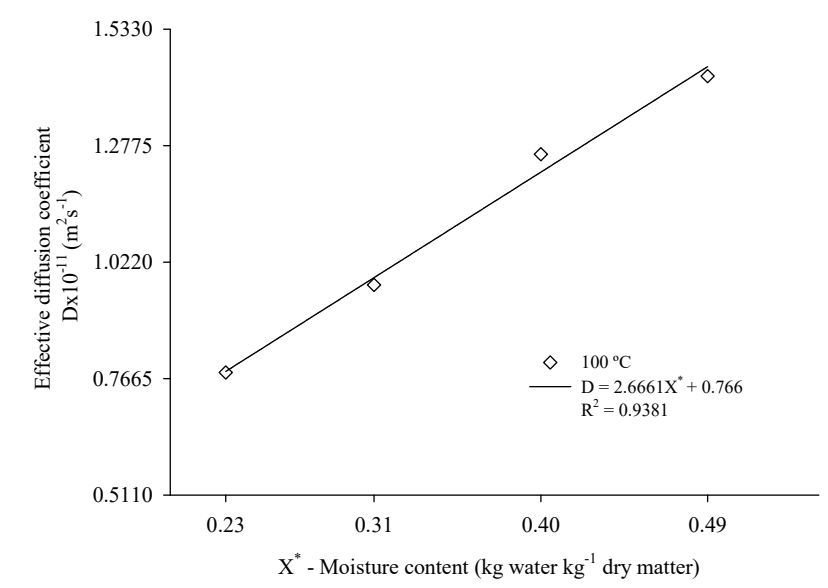

FIGURE 3. Values of effective diffusion coefficient $\left(\mathrm{m}^{2} \mathrm{~s}^{-1}\right)$ obtained for drying of sorghum grains at different initial moisture contents and temperatures of $40{ }^{\circ} \mathrm{C}(\mathrm{A}), 60^{\circ} \mathrm{C}(\mathrm{B}), 80^{\circ} \mathrm{C}(\mathrm{C})$, and $100{ }^{\circ} \mathrm{C}(\mathrm{D})$.

The values of the effective diffusion coefficient of sorghum grains increased linearly as temperature increased, corroborating the results reported by Botelho et al. (2015) for sorghum grains and Araújo et al. (2017) for peanut.

In addition, the increased temperature leads to an increase in the vibration of water molecules, which also contributes to the speed of the effective diffusion coefficient (Goneli et al., 2007). Therefore, the vibration level is lower at lower temperatures, allowing increasing the resistance of mass transfer and make it difficult for water to escape at a higher speed.

In this sense, the moisture content of the product also influences the vibration condition because the higher the water availability in the product is, the higher the vibration level of water molecules and, consequently, the higher the drying rate due to an increased diffusivity.
The effective diffusion coefficient of sorghum grains in relation to the drying air temperature was represented by the Arrhenius expression, which provides the Ea to $\mathrm{R}$ ratio, while the intersection with the ordinate axis indicates the Do value (Figure 4). The activation energy was calculated from the straight line of 27.32 , $26.75,22.55$, and $20.94 \mathrm{~kJ} \mathrm{~mol}^{-1}$ for initial moisture contents of $0.49,0.40,0.31$, and $0.23 \mathrm{~kg}$ water $\mathrm{kg}^{-1}$ dry matter, respectively.

An increase in the initial moisture content of sorghum grains led to an increase in the activation energy. Botelho et al. (2015) worked with two sorghum cultivars under moisture contents of 0.37 (BRS 308) and 0.39 (NIDERA A 9721) $\mathrm{kg}$ water $\mathrm{kg}^{-1}$ dry matter and found values of activation energy of 33.71 and $35.71 \mathrm{~kJ} \mathrm{~mol}^{-1}$, respectively. Both studies show that the highest activation energy occurred in grains with higher initial moisture content. 


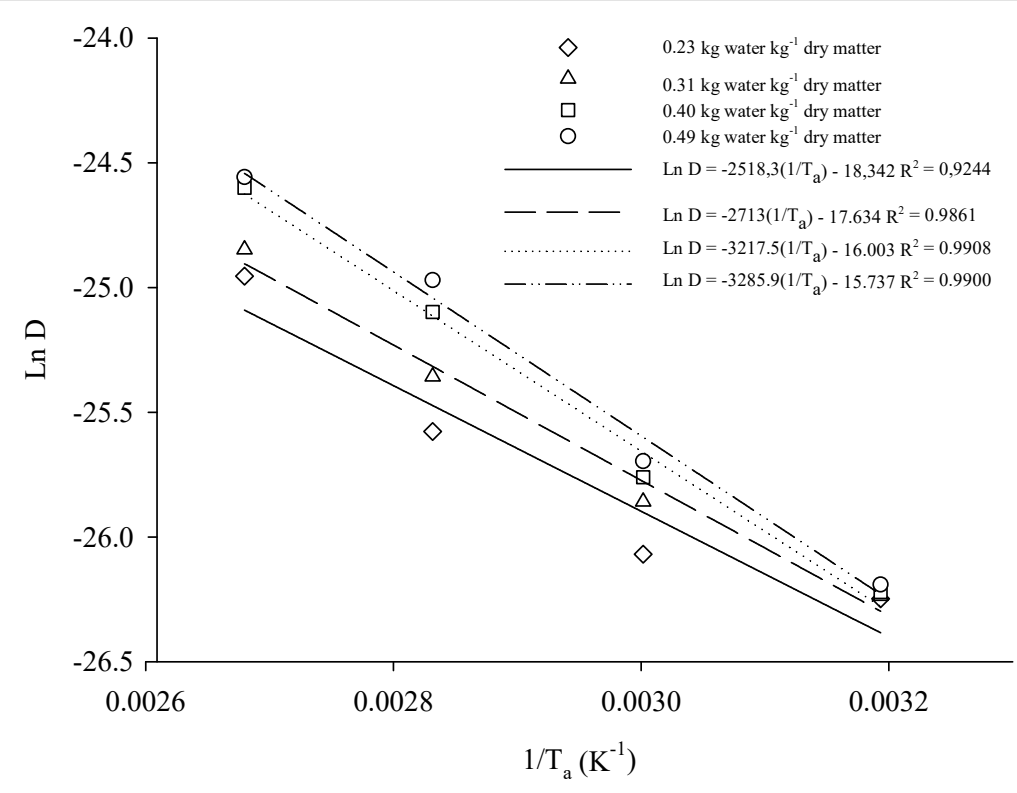

FIGURE 4. Arrhenius representation for the effective diffusion coefficient as a function of drying air temperature (40, 60,80 , and $100^{\circ} \mathrm{C}$ ) of sorghum grains at different moisture contents.

Resende et al. (2014) studied drying sorghum cultivar AS4620 with an initial moisture content of $0.228 \pm 0.003 \mathrm{~kg}$ water $\mathrm{kg}^{-1}$ dry matter at 40,50 , and $60^{\circ} \mathrm{C}$ under two different drying air speeds $\left(0.5\right.$ and $\left.1.0 \mathrm{~m} \mathrm{~s}^{-1}\right)$ and observed that the diffusion coefficient increased as drying air speed increased, i.e., from $0.638 \times 10^{-11}$ to 1.11 $\times 10^{-11} \mathrm{~m}^{2} \mathrm{~s}^{-1}$ for an air speed of $0.5 \mathrm{~m} \mathrm{~s}^{-1}$ and $1.024 \times$ $10^{-11}$ to $2.355 \times 10^{-11} \mathrm{~m}^{2} \mathrm{~s}^{-1}$ for a drying air speed of $1.0 \mathrm{~m}$ $\mathrm{s}^{-1}$ at the temperature range of 40 to $60^{\circ} \mathrm{C}$. Consequently, this increase in diffusivity increased the activation energy for the most diffusive condition, ranging from 27.12 to $42.05 \mathrm{~kJ} \mathrm{~mol}^{-1}$ for 0.5 to $1.0 \mathrm{~m} \mathrm{~s}^{-1}$, respectively, as observed in the present study. Similar values for activation energy were found for bean $\left(27.16 \mathrm{~kJ} \mathrm{~mol}^{-1}\right)$ (Morais et al., 2013).

Gely \& Giner (2007) worked with soybean and defined the activation energy for two drying temperatures, i.e., temperatures higher and lower than $50{ }^{\circ} \mathrm{C}$ led to values of activation energy of 28.80 and $16.60 \mathrm{~kJ} \mathrm{~mol}^{-1}$, respectively. As in the present study, the authors obtained higher values of activation energy for a situation of higher diffusivity. The authors attributed the increase of activation energy to high molecular mobility, similar to that observed for the drying of grain sorghum under different moisture contents, in which grains with higher moisture content had higher water mobility rate and, consequently, higher diffusivity and increased activation energy for the process to occur.

The highest energy consumption for drying sorghum grains under different moisture contents is attributed to the higher initial moisture content, as according to the transformation energy theory, high moisture content at the adsorbed and free states requires a higher energy demand to grains of lower moisture content for the desorption process to occur. According to Brooker et al. (1974), the amount of energy absorbed by the material during drying is directly related to its amount of water, leading to an increase in temperature and water evaporation.

The difference in activation energy for drying grain sorghum can also be explained by the glass transition temperature $(\mathrm{Tg})$, which varies as a function of the chemical composition of food, such as starch, and may influence texture stability and thickener and gelatinization properties (Guillon \& Champ, 2000), mainly of the moisture content. Roos \& Karel (1991) observed a decrease in $\mathrm{Tg}$ as product moisture content increased, as water causes a drastic reduction in $\mathrm{Tg}$ of food polymers.

A reduction in $\mathrm{Tg}$ causes different activation energy values to occur for different product moisture contents. Activation energy is weaker at lower temperatures due to material rigidity, with less free volume available for translational motion of water molecules. In addition, drying at high temperatures makes the material softer and more elastic, resulting in higher activation energy (Yang et al., 2003). Sorghum grains with higher initial moisture contents presented higher activation energy values due to higher exposure to temperatures higher than $\mathrm{Tg}$.

\section{CONCLUSIONS}

Effective diffusivity of sorghum grains increased at the same drying temperature as the initial moisture content of grains increased.

The activation energy was higher for grain sorghum grains with higher initial moisture content, with values of $27.32,26.75,22.55$, and $20.94 \mathrm{~kJ} \mathrm{~mol}^{-1}$ for initial moisture contents of $0.49,0.40,0.31$, and $0.23 \mathrm{~kg}$ water $\mathrm{kg}^{-1}$ dry matter, respectively.

\section{ACKNOWLEDGMENTS}

To IF of Goiás, CAPES, FAPEG, FINEP, and CNPq for the necessary financial support to carry out this research.

\section{REFERENCES}

Araújo WD, Goneli ALD, Souza CMA, Gonçalves AA, Vilhasantis HCB (2014) Propriedades físicas dos grãos de amendoim durante a secagem. Revista Brasileira de Engenharia Agrícola e Ambiental 18(2):279-286. 
Araújo WD, Goneli ALD, Hartmann CP, Martins EAS (2017) Modelagem matemática da secagem dos frutos de amendoim em camada delgada. Revista Ciência Agronômica 48(3):448-457.

Baptestini FM, Corrêa PC, Junqueira MS, Ramos AM, Vanegas JDB, Costa CF (2015) Modelagem matemática da terapia de espuma de graviola. Revista Brasileira de Engenharia Agrícola e Ambiental 30(19):1203-1208.

Botelho FM, Garcia TRB, Viana JL, Botelho SCC, Sousa AMBS (2015) Cinética de secagem e determinação do coeficiente de difusão efetivo de grãos de sorgo. Revista Brasileira de Milho e Sorgo 14(2):260-272.

Brooker DB, Bakker-arkema FW, Hall CW (1974) Drying cereal grains. Connecticut, The Avi Publishing Company, $265 \mathrm{p}$

CONAB - Companhia Nacional de Abastecimento (2017) Acompanhamento da safra brasileira: grãos safra 2016/2017- $1^{\circ}$ levantamento. CONAB. Available: http://www.conab.gov.br/Olalacms/uploads/arquivos/

Fernandes RVB, Queiroz F, Botrel DA, Rocha VV, Souza VR, Lima CF (2014) Study of the other album and da temperature of the occupation in features of polpa de tomato in powder. Semina: Ciências Agrárias 35(3):1267-1278.

Gely MC, Giner SA (2007) Diffusion coefficient relationships during drying of soybean cultivars. Biosystems Engineering 96(6):213-222.

Goneli ALD, Corrêa PC, Resende O, Reis AS (2007) Estudo da difusão de umidade em grãos de trigo durante a secagem. Ciência e Tecnologia de Alimentos 27(1):135-140.

Goneli ALD, Corrêa PC, Afonso PC, Oliveira GHH (2009) Cinética de secagem dos grãos de café descascados em camada delgada. Revista Brasileira de Armazenamento, Especial Café 11(1):64-73.
Guillon F, Champ M (2000) Structural and physical properties of dietary fibres, and consequences of processing on human physiology. Food Research International 33(1):233-245.

Madamba PS, Driscoll RH, Buckle KA (1996) The thin layer drying characteristics of garlic slices. Journal of Food Engineering 29(1):75-97.

Morais SJS, Devilla IA, Ferreira DA, Teixeira IR (2013) Modelagem matemática das curvas de secagem e coeficiente de difusão de grãos de feijão-caupi (Vigna unguiculata (L.) Walp.). Revista Ciência Agronômica 44(33):455-463.

Oliveira DEC, Resende O, Bessa JFV, Kester NA, Smaniotto TAS (2014) Mathematical modeling and thermodynamic properties for drying soybean grains. African Journal of Agricultural Research 10(2):31-38.

Resende O, Oliveira DEC, Chaves TH, Bessa JFV (2014) Kinetics and thermodynamic properties of the drying process of sorghum (Sorghum bicolor [L.] Moench) grains. African Journal of Agricultural Research 9(32):2453-2462.

Rodovalho RS, Silva HW, Silva IL, Rossetto CAV (2015) Cinética de secagem dos grãos de pimenta bode. Global Science and Technology (8):128-142.

Roos Y, Karel M (1991) Plasticizing effect of water on thermal behavior and crystallization of amorphous food models. Journal of food science 56(1):38-43.

Yang W, Jia CC, Siebenmorgen TJ, Pan Z, Cnossen AG (2003) Relationship of kernel moisture content gradients and glass transition temperatures to head rice yield.

Biosystems Engineering 85(4):467-476. 